\title{
Totalitaryzm jako zjawisko demaskujące Uwagi na temat Tischnerowskiego rozumienia totalitaryzmu
}

\author{
DOI: $10.35757 /$ CIV.2012.14.04
}

Tematem artykułu jest interpretacja doświadczenia totalitaryzmu w ujęciu Józefa Tischnera. Krakowski filozof nie jest kojarzony $z$ ta problematyka, poniższe rozważania sa więc nie tylko próba odpowiedzi na pytanie o to, jak rozumieć totalitaryzm w kategorii zjawiska demaskującego, ale także służa przybliżeniu nieznanego szerzej watku refleksji Tischnera ${ }^{1}$.

Gdyby spróbować zwięźle wyjaśnić, co zostaje zdemaskowane przez totalitaryzm widziany oczami Tischnera, można by powiedzieć: totalitaryzm demaskuje relacje międzyludzkie pozbawione etycznego wymiaru, jakim jest uwewnętrznione w każdym człowieku pragnienie dobra. Innymi słowy, totalitaryzm demaskuje relacje międzyludzkie opierające się na zasadzie odwetu, podszyte

\footnotetext{
Anna Siwek - filozof, doktor nauk o polityce, adiunkt w Zakładzie Filozofii Polityki Instytutu Studiów Politycznych Polskiej Akademii Nauk, sekretarz redakcji „Civitas. Studia z Filozofii Polityki”.

1 Polityka i jej zjawiska były dla Józefa Tischnera inspiracją rozważań na temat kondycji człowieka, nie stanowiły zaś głównego przedmiotu zainteresowania filozofa. Tischner to przede wszystkim myśliciel zwiąany $z$ filozofia człowieka, a także $z$ filozofia dialogu, które pozwoliły mu na wyartykułowanie autorskiego stanowiska filozoficznego, zwanego filozofia dramatu i agatologią. Jego najważniejsze książki opisują człowieka jako istotę dramatyczna, której los rozgrywa się w perspektywie wolności i dobra. Szerzej - por.: J. Tischner: Filozofia dramatu, Éditions du Dialogue, Paris 1990; idem: Spór o istnienie człowieka, Społeczny Instytut Wydawniczy „Znak”, Kraków 1998.
} 
strachem. Można wyrazić sens spojrzenia filozofa na totalitaryzm, nazywając go międzyludzkim światem wcielonego zła.

Wydaje się jednak, że takie ujęcie totalitaryzmu demaskuje także samego Tischnera jako interpretatora zjawiska totalitaryzmu. Zobaczmy, w jaki sposób się to dokonuje.

Zacznijmy od uwagi wstępnej, dotyczacej interpretacji zjawiska totalitaryzmu na gruncie nauk o polityce, aby zobaczyć, jak na ich tle sytuuje się spojrzenie Tischnera. Klasyczne rozumienie totalitaryzmu każe w nim widzieć przede wszystkim system sprawowania władzy oparty na specyficznej konstrukcji państwa, w której głównymi elementami sa: ideologia, partia o charakterze masowym, monopol nad armia, środkami walki zbrojnej i środkami przekazu, kontrola policyjna wykorzystująca terror, a także scentralizowana kontrola nad gospodarką. Opis tej dwudziestowiecznej formy rządzenia jest uzupełniany o następujące elementy: ruch totalitarny, irracjonalność ideologii totalitarnej, zniesienie rozdziału między państwem a społeczeństwem, rola charyzmatycznego przywódcy - wodza, propaganda czy brak pluralizmu w wielu dziedzinach życia ${ }^{2}$.

Odmienny sposób opisywania totalitaryzmu proponuja badacze mniej radykalnie zanurzeni $\mathrm{w}$ problematyce politycznej, ale pozostajacy pod silnym jej oddziaływaniem. Erich Fromm w słynnej koncepcji „ucieczki od wolności”, Theodor Adorno w teorii autorytarnej osobowości i piszacy o charakterze autorytarnym Abraham Maslow zwracaja uwage na psychologiczno-socjologiczne aspekty zwiąane $z$ doświadczeniem totalitaryzmu ${ }^{3}$.

2 Wątki te możemy odnaleźć np. u takich autorów, jak Carl Joachim Friedrich i Zbigniew Brzeziński, Hannah Arendt, Leonard Shapiro czy Juan José Linz. To sztandarowe nazwiska badaczy, którzy podejmuja refleksję nad totalitaryzmem rozumianym jako forma ustroju. Zob.: C.J. Friedrich, Z.K. Brzeziński: Totalitarian Dictatorship and Autocracy, Harvard University Press, New York 1956; H. Arendt: Korzenie totalitaryzmu, przekład M. Szawiel, D. Grinberg, Niezależna Oficyna Wydawnicza, Warszawa 1993; L. Shapiro: Totalitaryzm, Wydawnictwo Rytm, Warszawa 1987; J.J. Linz: Totalitarian and Authoritarian Regimes, w: F.I. Greenstein, N.W. Polsby (red.): Handbook of Political Science, Addison-Wesley, Reading 1975.

3 Por.: E. Fromm: Ucieczka od wolności, przekład O. i A. Ziemilscy, Czytelnik, Warszawa 1993; T. Adorno: Osobowość autorytarna, przekład M. Pańków, Wydawnictwo Naukowe PWN, Warszawa 2010; A. Maslow: Motywacja i osobowość, przekład J. Radzicki, Wydawnic- 
Józef Tischner nie sięga wprost do prac psychologicznych, niemniej jednak wykazuje intelektualną wrażliwość, sugerująca, że przedstawianie totalitaryzmu wyłącznie $z$ perspektywy struktury państwa i formy organizacji ustroju jest niewystarczające i nie wyczerpuje zagadnienia ${ }^{4}$. Być może spojrzenie krakowskiego myśliciela można potraktować jako swoisty pomost między typowo politologicznym opisem totalitaryzmu a jego innymi ujęciami, akcentujacymi np. aspekty psychologiczne. Dowodzą tego dwa wątki obecne $\mathrm{w}$ twórczości pisarskiej Tischnera. Pierwszy z nich to „ludzie z kryjówek”, drugi - „kraina schorowanej wyobraźni” ${ }^{\text {. Oba }}$ elementy dotyczą mentalno-psychicznej kondycji człowieka, zarazem zaś wskazuja specyficzny rys doświadczenia totalitaryzmu, a jest nim oddziaływanie przekraczające trwanie ustroju politycznego, $z$ którym tradycyjnie i stereotypowo wiąże się totalitaryzm. Zanim przybliżymy oba te elementy, zobaczmy formułę opisująca totalitaryzm jako międzyludzki świat wcielonego zła.

Jest tutaj wyrażone przekonanie Tischnera, że zło przybrało konkretny kształt - kształt relacji między ludźmi. Relacje te sa skażone. Czym? Myśleniem politycznym, które powoduje, że ludzie zadaja sobie nawzajem ból, czyli uczestniczą w złu, jak bowiem mówi Tischner, zło jak zjawa zjawia się między ludźmi i przybiera formę doznawanego lub wyrządzanego cierpienia ${ }^{6}$. W jaki sposób myślenie polityczne uczestniczy w złu? Ono w pewien sposób prowokuje, zachęca do wyrządzania krzywdy, ale także przygotowuje na cios, który może spaść na człowieka.

Dlaczego myślenie polityczne uczestniczy w złu? Co sprawia, że Tischner redukuje myślenie polityczne, sprowadzając je do wymiaru zła? Odpowiedź brzmi: za reprezentatywna wersję myślenia

two Naukowe PWN, Warszawa 2006. Opis różnych modeli autorytarnej osobowości - por. P. Radkiewicz: Autorytaryzm a brzytwa Ockhama, Wydawnictwo Naukowe „Scholar”, Warszawa 2012.

4 Por. M. Kuniński (red.): Totalitaryzm a zachodnia tradycja, Ośrodek Myśli Politycznej, Kraków 2006 [tu liczne artykuły i eseje wykraczające poza wąskie spojrzenie na totalitaryzm]. 5 J. Tischner: Ludzie z kryjówek, w: idem: Myślenie według wartości, Społeczny Instytut Wydawniczy „Znak”, Kraków 1993, s. 437-456; idem: W krainie schorowanej wyobraźni, Społeczny Instytut Wydawniczy „Znak”, Kraków 1997.

6 Zob. idem: Spór o istnienie..., s. 152-153. 
politycznego krakowski filozof przyjmuje jego totalitarna odmianę, którą uosabia łagier, czyli komunizm. Józef Tischner doskonale wie, że czerpiąc $z$ doświadczeń $\mathrm{XX}$ wieku, można wskazać również nazizm. Wybiera jednak komunizm, tłumacząc to, $z$ jednej strony, względami biograficznymi, $z$ drugiej zaś strony - przekonaniem o większej skali i sile oddziaływania na historię niż nazizm ${ }^{7}$.

Uznaje także, że komunistyczna koncepcja zła i związana $z$ nią koncepcja władzy okazała się bardziej zniewalająca. Innymi słowy, w komunizmie Tischner widzi odmianę totalitaryzmu, w której przejawiło się zło, jakiego głównym elementem jest specyficzne rozumienie, kim jest człowiek. Kluczem do totalitarnego rozumienia człowieka jest przekonanie, że racja jego istnienia jest władza: „[...] rządzę, więc jestem. Na tyle jestem, na ile rządzę”. Człowiek jest postrzegany jako istota kierująca się żądzą władzy, realizująca wyłącznie to pożadanie. Parafrazujac Martina Heideggera, Tischner może powiedzieć: człowiekowi w jego bycie nie chodzi o to bycie, ale o posiadanie - rzeczy, innych ludzi, władzy.

Organizacja rzeczywistości według zasad komunistycznych budzi w człowieku skłonności, które bez odpowiedniego pobudzenia nigdy by się nie urzeczywistniły. Zobaczmy te skłonności. Określenie człowieka jako żądnego władzy ułatwia zniewolenie go przez tych, którzy posługuja się totalitarna ideologia, będąca pułapką zastawiona na wolność człowieka. Dlaczego tak się dzieje? Przede wszystkim ze względu na rodzaj władzy, jaką oferuje ideologia totalitarna - treścia totalitarnej pokusy władzy jest hasło: „[...] ma władzę ten, kto ma człowieka”. W tym duchu Tischner interpretuje komunistyczne postulaty zniesienia własności pry-

\footnotetext{
7 Por. ibidem, s. 41. Warto dodać, że Tischner, analizując komunizm pod katem jego totalitarnego charakteru, włącza się $\mathrm{w}$ istniejący nurt refleksji, której przedstawicielami sa np. Alain Besançon (por. A. Besançon: Przekleństwo wieku. O komunizmie, narodowym socjalizmie i jedności zagłady, przekład J. Guze, Czytelnik, Warszawa 2000; idem: Anatomia widma. Ekonomia polityczna realnego socjalizmu, przekład W. Dłuski, Res Publica, Warszawa 1991) czy Jacob L. Talmon, który przedstawił studium opisujace państwo sowieckie (por. J.L. Talmon: The Origins of Totalitarian Democracy, Seecker and Warburg, Boston 1952).

8 J. Tischner: Spór o istnienie..., s. 55.

9 Ibidem, s. 41.
} 
Totalitaryzm jako zjawisko demaskujace...

watnej, uspołecznienia środków produkcji czy likwidacji wyzysku - sa to po prostu zewnętrzne formy totalitarnego zamachu na człowieka. Widać to w sposobie realizacji tych postulatów, który nie przynosi obiecywanej poprawy jakości życia, ale instrumentalizuje wysiłki ludzi do realizacji koniecznego procesu ustanawiania sprawiedliwości społecznej. W ten sposób egzystencja człowieka zostaje pozbawiona cech indywidualnych, staje się zaś częścią machiny dziejowej - jednostkowy człowiek traci na wartości, istotny jest ogół, dla którego dobra należy poświęcić indywidualne cele i pragnienia. I tutaj zaczynaja się budzić w człowieku skłonności dotąd uśpione: jest gotów poświęcić wszystko to, co jest mu bliskie, co jest dla niego wartościowe - więzi z najbliższymi, z rodzina - żeby udowodnić, że jest lojalnym obywatelem, darzącym władzę zaufaniem. Nie zauważa, że w ten sposób traci wolność i niczym Nietzscheański nadczłowiek przewartościowuje wartości: jest $\mathrm{w}$ stanie składać donosy na najbliższych, czym udowadnia lojalność wobec władzy i potwierdza ideologię, głosząca, że więzy $z$ najbliższymi są dobre, jeśli służą władzy politycznej ${ }^{10}$.

$\mathrm{Na}$ tym jednak nie wyczerpuje się kreatywność człowieka. Jest on także w stanie zaakceptować przemoc. Jak pisze Tischner, $\mathrm{w}$ świadomości pojawia się „[...] zaszczepione przekonanie, że $\mathrm{w}$ imię wartości najwyższych, reprezentowanych przez komunistyczną władzę, człowiek może, a nawet powinien poświęcić wartości najbliższe. Kołyma jest urzeczywistnieniem starej pokusy Abrahama, od którego Bóg zażądał ofiary $z$ syna. W Biblii nie doszło do takiej ofiary, tymczasem w komunizmie do niej doszło"11. Gdzie szukać źródła tak zdeformowanego myślenia człowieka, rozumiejącego, że warto poświęcić własne życie lub życie bliskich $\mathrm{w}$ imię realizacji totalitarnych postulatów? Wytłumaczenie tkwi w specyficznym heroizmie, jaki cechuje mentalność człowieka poddanego totalitarnej władzy, w heroizmie, który nie byłby możliwy,

\footnotetext{
10 „Totalitaryzm znaczy tutaj nie tylko to, że władza obejmuje całość życia społecznego, ale przede wszystkim to, że wkracza w intymność człowieka, w której maja swą naturalna podstawę więzi z najbliższymi" (ibidem, s. 53).

${ }^{11}$ Ibidem, s. 48.
} 
gdyby nie założenie antropologiczne, że władza to sens istnienia człowieka. Specyficzny heroizm, o którym tutaj mowa, pozwala odrzucić dobro jako motyw działania ludzkiego - „[...] trzeba mieć odwage czynienia zła, by ze zła mogło wypływać dobro"12. Odwaga czynienia zła przyjmuje konkretne oblicze: odebrania życia drugiemu człowiekowi. Odwagi tej nie wystarczyłoby człowiekowi, gdyby nie założenie, że jest on przede wszystkim istota pragnaca władzy. Przypomnijmy: „[...] wyrazem władzy jest możliwość odebrania życia innemu. Zabijając innego, potwierdzam swe prawo do istnienia"13.

Zastanówmy się nad tym, dlaczego człowiek zabija. Czy wystarczająca odpowiedzia jest wskazanie natury ludzkiej, czyli pragnienie władzy? Tischnerowi to nie wystarcza, zauważa bowiem, że władza mogła stać się władzą darowania życia, stała się jednak władza zabijania, a skoro tak, to oznacza, że „[...] do pragnienia władzy i lęku przed jej utrata dołącza się [...] umiłowanie zła jako zła, które mówi nie każdemu napotkanemu dobru. A nawet jeśli dopuszcza istnienie dobra, to tylko chwilowo, by móc je zanegować w przyszłości”" ${ }^{14}$. Skłonnościa, która uruchamia totalitaryzm, jest zatem żarliwa miłość do zła, przy czym człowiek kocha zło wyłącznie $z$ jednego powodu - ponieważ ono istnieje. Takie uczucie to deformacja, która jest negacja etycznego nastawienia człowieka, wyrażającego się $\mathrm{w}$ intuicyjnym dążeniu do dobra i unikaniu zła. Innymi słowy, dobro $i$ zło to perspektywa, $z$ której, zdaniem Tischnera, powinniśmy patrzeć na totalitaryzm, gdyż wyłącznie wtedy uwidacznia się podstawowa przestrzeń, w której totalitaryzm dokonuje spustoszenia - jest nią duchowa wrażliwość etyczna człowieka.

Jakimi meandrami biegna myśli człowieka, w którym dokonało się opisywane przez krakowskiego filozofa wyjałowienie etycznej wrażliwości? Zdaniem Tischnera, zdrowy rozsądek, którym zwykle i naturalnie posługuje się człowiek, zostaje zastapiony przez

12 Ibidem, s. 53.

13 Ibidem, s. 55.

${ }^{14}$ Ibidem. 
myślenie polityczne, prowadzące go do specyficznej kreatywności $\mathrm{w}$ zakresie tworzenia jednej i jedynej prawdy - prawdy w jej politycznej odmianie. Proces tej substytucji rodzajów myślenia przebiega łagodnie, ponieważ zdrowy rozsądek „[...] nastawiony wyłącznie na opisywanie prawdy, budzi się zbyt późno, gdy dzieło jest już gotowe, a wtedy staje się zniewolony jego czarem [...]. Dzieło polityczne nie oddziałuje na niego innymi środkami niż moc utworzonej prawdy. Sowa Minerwy wylatuje o zmroku i wydobywa na jaw jako prawdę dziejów to, co zbudował rozum polityczny. Nie potrzeba lęku, by mógł powstać umysł zniewolony"15.

Dochodzimy tutaj do rdzenia relacji międzyludzkich spełniajacych się w totalitarnym świecie, których zasada jest podejrzliwość - królowa cnót totalitarnej ideologii, wyrażana w zlęknionym poszukiwaniu sojuszników i wrogów. Świat wcielonego zła to świat lawinowo wzrastajacej międzyludzkiej podejrzliwości, która wskazuje logikę postępowania zgodna w głosem rozumu politycznego i podszyta strachem: nie można przestać bać się drugiego człowieka, należy zatem wykazać się czujnością i dalekowzrocznościa, które oznaczaja, że trzeba go zniewolić, podporządkować. Podejrzliwość, która opisuje filozof, prowadzi do przyjęcia zasady odwetu jako pierwotnego sposobu odniesienia wobec drugiego. Można stwierdzić, że u Tischnera dokonuje się obnażenie istoty myślenia politycznego, które nie jest niczym innym, jak dewastacją człowieczeństwa. Innymi słowy, kierując się rozumem politycznym, człowiek zamyka przed soba drogę do doświadczenia wolności i czyni niemożliwą relację pozytywnej więzi z drugim człowiekiem: „[...] myślenie polityczne jest zaraźliwe; rozprzestrzenia się nie dzięki odsłanianym prawdom, tylko tak jak zaraza - poprzez sama styczność"16.

\footnotetext{
${ }^{15}$ Idem: Filozofia dramatu..., s. 132. Szerzej na temat rozumu pospolitego i jego zainfekowania myśleniem politycznym - por. np. idem: Kłamstwo polityczne. $Z$ badań nad istota stalinizmu, w: idem: Polski młyn, „Nasza Przeszłość”, Kraków 1991, s. 119-132.

${ }^{16}$ Idem: Filozofia dramatu..., s. 134. Przykładem zainfekowanej relacji międzyludzkiej charakterystycznej dla realiów myślenia politycznego jest kłamstwo, które ma wyłącznie destrukcyjny wpływ na myślenie i postawę człowieka. Uruchamia ono schemat: zostałem okłamany,
} 
Podsumowując, można powiedzieć, że w perspektywie krakowskiego filozofa relacje międzyludzkie opierają się na regułach postępowania podpowiadanych przez wszechobecny i dominujacy rodzaj myślenia politycznego. W opisie Tischnera istnieje wyłacznie jedna rzeczywistość, rządząca się według podejrzliwości nakłaniającej do odwetu. I właśnie odpowiedzialność totalitaryzmu za taki stan rzeczy filozof demaskuje. Józef Tischner nie chce widzieć w totalitaryzmie formy ustrojowej ani porzadku politycznego ze specyficzna struktura władzy, gdyż takie ujęcie daje niepełny obraz doświadczenia totalitaryzmu. Chcąc je w pełni zrozumieć - jeśli w ogóle jest to możliwe - musimy zapytać o człowieka i przyjrzeć się jego duchowi, mentalności i postawie etycznej. W tym ujęciu warto zapamiętać zdanie krakowskiego filozofa, głoszące, że „Kołymę nosi się w sobie"17. Należy podkreślić, że dla Tischnera w tym właśnie kryje się podstawowy sens totalitaryzmu: to odczłowieczenie istoty ludzkiej, która nie łaknie już dobra, zarazem jednak nie dostrzega własnego uczestnictwa $\mathrm{w} \mathrm{złu}^{18}$.

Powróćmy w tym miejscu do Tischnerowskich sentencji o „ludziach z kryjówek” i „krainie schorowanej wyobraźni”, opisują one bowiem odczłowieczoną egzystencję jednostki naznaczonej piętnem totalitaryzmu. Kim sa „ludzie $z$ kryjówek”? Józef Tischner pisze o tym w eseju z 1978 roku (który jest w istocie recenzja książki znanego krakowskiego psychiatry Antoniego Kępińskiego Psychopatie): „[...] człowiek żyje na poziomie nijakości, poza dobrem i złem, jest ani winny, ani niewinny, jego odpowiedzialność znalazła się w stanie uwiądu [...] cała godność człowieka sprowadza się do wartości cierpień, którym podlega. Znamiennym rysem

dlatego i ja okłamię. Człowiek nie znajduje powodu, żeby powstrzymać się od kłamstwa, co sprawia, że podejrzewa o tę samą postawę wszystkich wokół. Wątkowi temu Tischner poświęcił, wspomniany wyżej, esej Kłamstwo polityczne...

${ }_{17}$ Idem: Spór o istnienie..., s. 47. Nie jest to jedyne miejsce i jedyny kontekst, w jakich filozof posługuje się tą symbolika. Por. idem: Niebo w nowych płomieniach, w: idem: W krainie schorowanej wyobraźni, Społeczny Instytut Wydawniczy „Znak”, Kraków 2002, s. 35-54. Kołyma jest tutaj pokazana jako rzeczywistość, którą można pokonać, czego przykładem jest postawa ks. Jerzego Popiełuszki.

${ }^{18}$ Por. idem: Labirynt schorowanej woli, w: idem: Polski mlyn..., s. 233-244. 
ludzi z kryjówek jest to, że sami cierpią i innym przysparzaja cierpień"19.

Widać tutaj dwie cechy charakterystyczne: po pierwsze, człowiek zatracił etyczny wymiar własnego życia, po drugie, jest on przede wszystkim istota cierpiąca, traktująca cierpienie jako formę komunikacji $z$ innymi. Dla Tischnera śladem totalitaryzmu w człowieku jest nieumiejętność pokonania lęku - któż bowiem, jeśli nie człowiek zlękniony, chowa się w kryjówce? - co przejawia się $\mathrm{w}$ przysparzaniu cierpienia innym. Lęk pcha człowieka do ukrycia się, mimo że powód lęku minął. Co to oznacza? Można powiedzieć: system polityczny nazywany totalitarnym został rozbrojony, pozostali jednak ludzie $z$ mentalnościa ukształtowana pod jego wpływem. Mentalność ta, naznaczona lękiem, jest zaś zatruta przez "chorobę nadziei”. Chora nadzieja nie oczekuje od innych ludzi dobra, nie oczekuje wsparcia i przyjaźni, kieruje nią bowiem „zasada ucieczki od ludzi” ${ }^{20}$. W ten sposób Tischner wytacza ciężki zarzut wobec totalitaryzmu, zostawiając nas $z$ pytaniem o lekarstwo na lęk i niedomaganie nadziei. Gdzie należy szukać życiodajnych źródeł ludzkich nadziei, które odbudowywałyby relacje między ludźmi?

Zobaczmy, co wyraża druga formuła, czyli czym jest „kraina schorowanej wyobraźni"? Czy to także scheda po komunistycznych rządach, które podpierając się ideologia wyrażoną w haśle: „Kto nie $z$ nami, ten przeciwko nam”, zrodziły w ludziach przekonanie, że władza jest jedynym miernikiem prawdy? Czy kraina schorowanej wyobraźni to Polska okresu transformacyjnego? A może to raczej metaforycznie wyrażona przypadłość mentalności ludzkiej występującej niezależnie od szerokości geograficznej?21 Szukając odpowiedzi, sięgnijmy po artykuł naszego autora zatytułowany Re-

\footnotetext{
${ }^{19}$ Idem: Ludzie z kryjówek..., s. 438.

${ }^{20}$ Ibidem.

${ }^{21}$ Za pierwszą odpowiedzią przemawia to, że w książce $W$ krainie... znajduje się cykl artykułów dotyczących polskiego oblicza religijności, a samą formułę „schorowanej wyobraźni” Tischner zaczerpną od Cypriana Kamila Norwida. Za druga odpowiedzia przemawiaja $z$ kolei okoliczność, że artykuły te zawierają opisy mentalnej optyki naznaczonej totalitarnym rysem o charakterze uniwersalnym.
} 
ligia polityczna, w którym znajdziemy opis religijnego aspektu totalitarnej pokusy rodzącej się w myśleniu człowieka: „[...] ze strachu przed soba i innymi oddać się w niewolę władzy i wierzyć, że Bóg tak chciał"22. Znakiem totalitarnego charakteru myślenia jest kategoria władzy, której człowiek pragnie się podporządkować, rezygnując tym samym $z$ wolności, zgodnie $z$ przekonaniem - czy może raczej $z$ głęboka wiara - że władza to jedyny godny pożądania i oddania obiekt. Człowiek $z$ mentalnościa zdeformowana totalitarnym skażeniem pada na kolana przed potęga, jaka jest władza, i w ten sposób pokazuje, że wciąż jest w nim żywy jej mit jako źródła prawdy i wolności: „[...] prawda jest niewatpliwie wartościa, ale pod warunkiem, że daje władzę. Wolność? Tak, to wielka wartość, ale pod warunkiem, że dążenie do niej otwiera drogę do władzy"23. Można śmiało stwierdzić, że opis religijnego charakteru myślenia politycznego jest dla Tischnera przykładem obecności totalitarnej ideologii $\mathrm{w}$ mentalności człowieka, co jest niezależne od systemu politycznego, w którym żyje. Jest to tym samym rozwinięcie podstawowej - etycznej - perspektywy przyjętej przez filozofa w spojrzeniu na totalitaryzm.

Powróćmy do pytania postawionego na początku: w jaki sposób perspektywa przyjęta przez Tischnera demaskuje go jako badacza totalitaryzmu? Zwróćmy uwage na dwie kwestie. Po pierwsze, filozof widzi w polityce źródło zła, co niewątpliwie zawęża perspektywę jego myślenia i nie tłumaczy, jak w totalitarnych warunkach były możliwe bunty wobec systemu oparte na relacjach międzyludzkich innych niż podejrzliwość i odwet. Jest to intrygujące pytanie, zważywszy na to, że Tischner opisywał np. „karnawał” pierwszej Solidarności, dokumentując tamten czas w Etyce solidarności, w której podkreślał, że duch solidarności wyrastał $z$ etycznego poruszenia ludzkich sumień niezasłużonym cierpieniem innych - bliźnich ${ }^{24}$. W jaki sposób było możliwe w świecie wcielonego zła dostrzeżenie

${ }^{22}$ Idem: W krainie..., s. 70.

${ }^{23}$ Ibidem.

${ }^{24}$ Zob. idem: Etyka solidarności i Homo sovieticus, Społeczny Instytut Wydawniczy „Znak”, Kraków 1992. 
w drugim człowieku bliźniego wzywającego pomocy? Czy wiąże się to $z$ jakimś pozytywnym potencjałem tkwiacym $\mathrm{w}$ polityce? Ciekawe, w jaki sposób Tischner odpowiedziałby na te pytania, kierujac się własnym spojrzeniem na totalitaryzm. Interesujacca wydaje się także kwestia, czy ujęcie totalitaryzmu przez pryzmat relacji międzyludzkich nie czyni $z$ tego pojęcia narzędzia, którym można opisywać zideologizowaną rzeczywistość nie tylko państw komunistycznych, ale także państw demokratycznych? Skoro totalitaryzm dotyczy przede wszystkim kondycji etycznej człowieka, to $z$ jej rozmaitymi odmianami mamy do czynienia $i \mathrm{w}$ innych politycznych okolicznościach. Wtedy powstaje zasadne pytanie o jakościowe różnice między np. PRL a demokratycznym państwem prawa.

I druga kwestia, która demaskuje Tischnera jako interpretatora zjawiska totalitaryzmu. Perspektywa ujęcia totalitaryzmu wpisuje się on $\mathrm{w}$ dyskusję toczona $\mathrm{w}$ filozofii europejskiej na temat genezy zła. Unde malum? - to pytanie elektryzowało od dawna umysły filozofów i teologów. Po zbrodniach popełnionych w imię komunistycznych i nazistowskich ideałów stało się ono jeszcze bardziej dojmujące. Odpowiedź „ciasnego i tępego filozofa Sarmatów"25 na pytanie o zło koncentruje uwage na człowieku, ponieważ wyłącznie on ponosi odpowiedzialność za własne czyny wyrażające stosunek do drugiego człowieka. Innymi słowy, człowiek jest sprawca zła, uczestniczy w nim, pozwala mu się uwodzić, gra i igra $z$ nim. Jak się wydaje, jest to jedynie częściowa odpowiedź na pytanie o źródła zła. Czy istnieje - a jeśli tak, to na czym polega teologiczny sens doświadczenia totalitaryzmu? Czy XX wiek

\footnotetext{
${ }^{25}$ Określenie to nadał Tischner samemu sobie, co pokazuje, że jego refleksja nad m.in. totalitaryzmem jest zakorzeniona w polskim doświadczeniu historycznym: „W mojej naturze leży egoizm. Nie mam zamiaru ratować nadziei Niemców, pokazując im Husserla, ani Francuzów ucząc ich Bergsona czy Ricœura. Ja sam jednak nie mogę nie znać tych panów. Powinienem ich znać, bo $z$ tego może być pożytek $\mathrm{w}$ szukaniu odpowiedzi na pytania zrodzone na tej ziemi. Egoizm jest zawsze źródłem ciasnoty. Wybrałem, aby być ciasnym i tępym filozofem Sarmatów. Staram się im wymyślać i dobrze im radzić. Na szczęście niezbyt mnie słuchaja, więc i wina moja nie będzie zbyt wielka" (idem: Czym jest filozofia, która uprawiam, w: idem: Myślenie według wartości..., s. 11).
} 
nie wymusza na nas współczesnej wersji teodycei? Dlaczego świat, który mógłby być wolny od zła, staje się miejscem jego wcielenia? Te pytania $\mathrm{w}$ refleksji Tischnera nie zajmuja pierwszoplanowego miejsca, choć warto $\mathrm{w}$ tym miejscu nadmienić, że krakowski filozof podjał próbę opisu totalitaryzmu $z$ perspektywy judeochrześcijaństwa, uważając, że doświadczenie totalitaryzmu może zbliżyć do siebie chrześcijan i Żydów. Wspólnie przeżyte cierpienia moga stać się podstawa głębokiego dialogu. W eseju Totalitarne wyzwanie. Judaizm i chrześcijaństwo wobec totalitaryzmu dwudziestego wieku określił totalitaryzm mianem neopogaństwa, a rozumiał je nie jako zjawisko historyczne, ale „[...] wciąż niespokojny i burzący się, wewnętrzny żywioł niespokojny człowieka, który daje znać ze szczególną siła, gdy szczyt ludzkiej duszy usłyszy boże wezwanie lub poczuje dotknięcie wodą chrztu. Żywioł ten stwarza w człowieku niezwykła podatność na pogańskie pokusy" ${ }^{26}$. Pogaństwo, za nim zaś totalitaryzm, to dla Tischnera przede wszystkim stan ducha ludzkiego, rodzacy się za sprawą odpowiedniego pobudzenia zewnętrznego, ale zarazem pobudzenia trafiajacego na podatny grunt, którym jest gotowość do podporządkowania się logice politycznego myślenia. Sa to refleksje stanowiące $z$ pewnością o specyfice Tischnerowskiej refleksji nad totalitaryzmem, nieodpowiadające jednak na pytanie o teologiczny sens totalitarnej pokusy, wobec której człowiek postawił samego siebie. A może należałoby stwierdzić inaczej, bardziej w duchu intelektualnej postawy Tischnera: nie odpowiadaja na pytanie o teologiczny sens totalitarnej pokusy, przed która Bóg postawił człowieka.

${ }^{26}$ Idem: Totalitarne wyzwanie. Judaizm i chrześcijaństwo wobec totalitaryzmu dwudziestego wieku, w: Polski młyn..., s. 154. 